\title{
EVALUASI SISTEM PENGENDALIAN INTERNAL BAHAN BAKU
} PRODUKSI PADA UD. XYZ DI SIDOARJO

\author{
Darno $^{1}$, Anita ${ }^{2}$, Jaya Adi Gama Tengtarto ${ }^{3}$, Kuswana Rama ${ }^{4}$, Camelia Dewi $\mathbf{R}^{5}$ \\ Institut Ilmu Sosial dan Manajemen STIAMI \\ Email: darno@dosen.umaha.ac.id ${ }^{1}$, siwal1703@gmail.com ${ }^{2}$, jack.tengtarto@gmail.com ${ }^{3}$, kuswanarama@gmail.com ${ }^{4}$, \\ camelia dewirachmawati@student.umaha.ac.id ${ }^{5}$
}

\section{ARTICLE INFO \\ Article History \\ Received 9 November 2020 \\ Revised 18 November 2020 \\ Accepted 27 November 2020}

\section{Keywords :}

Internal Control System, and Production Process.

\section{ABSTRACT}

The era of globalization, the industrial world is increasingly developing, there are many companies engaged in the industry that manage various kinds of products, there will be more competitive competition. The development of the company is increasing rapidly, with the level of use and need for raw materials that are relatively large and increasing consumer demand. Raw material inventory control system for its role is needed in companies with existing theories. The author intends to analyze "Evaluation Of The Internal Control System For Raw Material For The Smoothness Of The Production Prosess (Case Study at UD. XYZ di Sidoarjo)". The purpose of this study is to find out how the internal control system for raw material inventory can be used to facilitate all production processes or processing of raw materials at UD. Light Plastic Sidoarjo. The data analysis technique used and carried out is a qualitative descriptive technique, which is to compare the collected data on a theoretical basis as a reference material that provides several suggestions for problem solvers in writing. Based on the results of research that can be done that the processing process in the company includes: the stage of purchasing raw materials, the stage of storing raw materials, the processing stage, the distribution stage. The research was conducted using a case study approach with qualitative methods. Data collection methods are carried out, namely interviews, observation and documentation. Based on the analysis, it is concluded that the internal control system for raw material inventory can expedite the processing or production process in the company which is said to be good, but there are still some weaknesses, namely concurrency in work, lack of monitoring of the production process or processing time and the entry and exit of goods in the company.

\section{PENDAHULUAN}

Era globalilsasi, dunia industri semakin berkembang terdapat berlimpah perusahaan bergerak dalam mengelola berbagai macam produk, akan banyak persaingan yang lebih kompertitif. Perusahaan harus memiliki strategi tersendiri agar mampu bersaing baik itu dalam kualitas barang, strategi pemasaran yang baik serta hubungan yang baik dengan konsumen. Pengendalian persediaan bahan baku otoriter diperlukan akibat jumlah persediaan akan menentukan atau mempengaruhi kelancaran proses produksi bersama keefektifan dan efesiensi perusahaan.

UD. XYZ di Sidoarjo, bahan baku yang digunakan untuk pembuatan biji plastik diantaranya barang bekas plastik sampah pertokoan, mall2, dan afal pabrik (Biji Plastik Daur Ulang). Bahan baku yang dimiliki dan dipesan lansung pada distributor bisa melengkapi proses produksi dengan diharapkan mutu, kualitas yang bagus. Bahan baku terbilang cukup tersedia supaya proses produksi lancar supaya permintaan pelanggan kita terpenuhi. UD. XYZ di Sidoarjo memiliki permasalahan ketika lalai pada salah satu kewajiban dengan persediaan akan memicu perusahaan bisa mengalami suatu masalah, penting untuk perusahaan melakukan pengendalian persediaan sebagai upaya mempertahankan aktivitasnya secara setabil kemudian terkendali mampu menjaga persediaan stabil.

UD. XYZ di Sidoarjo dapat untuk dapat menjamin kelangsungan dalam operasi kegiatan dalam perusahaannya kemudian dapat mencapi tujuan serta target agar dapat meningkatkan nilai dalam perusahaan, diadakan tindakan yang terarah untuk mengendalikan persediaan yang terdapa di perusahaan untuk mencapai hasil atau keuntungan yng layak berkaitan dengan hasil bahan baku jadi, diperlukan pengendalian persediaan 
E-ISSN 2621-6442

sehingga dapat menekan proses produksi dengan biaya-biaya operasional sekecil mungkin, sehingga dapat mengoptimalkan kinerja perusahaan kita, persediaan terdapat beberapa macam barang yakni menjadi objek pokok aktivitas perusahaan yang tersedia untuk diolah dalam proses proses produksi atau jual (Syakur, 2009). Persediaan akan sangat rentan pada kerusakan dan pencurian, sehingga perlu adanya pengendalian internal bertujuan untuk menjaga bahan baku dan juga agar informasi terkait dengan persediaan bisa lebih kuta kepercayaanya.

\section{TINJAUAN PUSTAKA}

Sistem Pengendalian Internal

Menurut Ardiyos (2010) dalam Kamus Besar Akuntansi, pengendalian intern adalah suatu sistem yang direncanakan guna membantu pimpinan perusahaan dalam pengendalian kelancaran operasional perusahaan mencegah kemungkinan terjadinya penyelewengan, mengurangi tingkat kesalahan dan mendorong ditaatinya kebijaksanaan yang telah ditetapkan. Menurut Hery (2009), pengendalian intern adalah seperangkat kebijakan dan prosedur untuk melindungi aktiva atau kekayaan perusahaan dari segala bentuk tindakan penyalahgunaan, menjamin tersedianya informasi akuntansi perusahaan yang akurat, serta memastikan bahwa semua ketentuan (peraturan) hukum atau undang-undang serta kebijakan manajemen telah dipatuhi atau dijalankan sebagaimana mestinya oleh seluruh karyawan perusahaan.

Konsep sistem pengendalian internal perusahaan terhubung pada pengendalian internal perusahaan terhadap stok meliputi perhitungan fisik yang harus dilakukan pada setiap tahunya, atas dengan cara melakukan itu perusahaan akan mengetahui secara akurat jumlah persediaan yang ada. Namun apabila kesalah terjadi atas catatan akutansi akan didiskusikan sehingga menjadi sama dengan hasil perhitungan fisik dari barang tersebut. Perlu dilakukan pemisahan antar pegawai yang menangani stok dari catatan akuntansi. Kebijakan pencatatan yang dijalankan dengan tepat mampu memberikan perlindungan pada persediaan yang di terapkan pada perusahaan. Pemecahan tanggung jawab fungsiional serta sistem mutlak dan prosedur pencatatan yang sudah dalam setiap pelaksanaanya. Beserta terapan unsur-unsur pengendalian internal dalam pengolahan dan pengendalian persediaan barang, sistem pengendalian internal dapat terlaksana dengan tepat.

Menurut Imam Santoso (2007), jenis-jenis persediaan dikelompokkan sebagai berikut :

1) Bahan baku

2) Barang dalam proses

3) Barang jadi

4) Bahan pembantu

Menurut Handoko (2000;335-336), menyatakan bahwa perusahaan melakukan penyimpanan persediaan barang karena berbagai fungsi sebagai berikut, yaitu

1) Fungsi Decoupling

2) Fungsi Economic Lot

3) Fungsi Antisipasi

Unsur-Unsur Sistem Pengendalian Intern Persediaan (Mulyadi, 2008:166):

(1) Tatanan Organisasi

(2) Praktik

(3) Sistem wewenang dan prosedur pencatatan

(4) Karyawan

Menurut Darno dan Riska A (2020) dalam Hubungan Cash Flow Terhadap Kapasitas Produksi Pada PT Vista Mitra Surabaya, Biaya Bahan Baku berpengaruh tidak begitu signifikan terhadap Output Produksi. Namun demikian, strategi alternative untuk organisasi (perusahaan) dalam meningkatkan kinerjanya, slaah satunya dengan peningkatan efektifitas dan efisiensi manajemen operasi (D Darno, 2015) didalamnya termasuk manajemen persediaannya.

\section{METODE PENELITIAN}

Desain penelitian ini mengunakan metode pendekatan kualitatif yaitu analisis deskriptif, metode ini akan menganalisis gambaran sistem pengendalian internal persediaan bahan baku guna kelancaran dalam proses produksi pada UD. XYZ di Sidoarjo apakah sudah diterapkan dengan sesuai dengan unsur pengendalian intern atau belum. 
1. Data primer yaitu suatu data yang diperoleh langsung dari subjek penelitian, untuk hal ini peneliti mendapat data dan informasi secara lansung dengan menggunakan unsur-unsur yang telah ditetapkan.

2. Data Sekunder yaitu sumber data penelitian yang didapat oleh peneliti secara tidak langsung lewat media pelentara (didapat dan dicatat dengan pihak lain).

1) Data internal adalah didapat dari tempat yang ditelliti seperti dokumen perusahaan, catatan barang masuk, barang dalam proses dan barang keluar, struktur organisasi perusahaan.

2) Data eksternal yaitu didapat dari luar tempat penelitian seperti internet dan perpustakaan.

\section{Teknik Pengumpulan Data}

Cara yanng dapat dilakukan peneliti untuk mengumpulkan semua data, ada berbagai macam cara mengumpulkanya :

1. Wawancara

Wawancara adalah teknik tanya jawab, tatap muka secara langsung peneliti dan narasumber.

2. Observasi

Observasi adalah pengumpulan data yang melibatkan berbagai faktor dalam pelaksanaanya. pengumpulan data yang dilakukan dengan cara mendatangi langsung ke tempat yang diteliti yaitu UD. XYZ di Sidoarjo dan melakukan pengamatan secara langsung untuk mencatat dan mencari informasi yang berkaitan dengan masalah yang akan diteliti.

3. Studi Dokumen

Studi dokumen adalah metode pengumpulan data yang tidak ditunjukkan langsung kepada subjek penelitian. Studi dokumen berguna untuk bahan analisa, ada 2 studi dokumen yaitu dokumen primer dan dokumen sekunder dan peneliti mengunakan keduanya untuk kebenaran yang ilmiah.

\section{Pengujian Keabsahan Data}

Keabsahan data untuk mengetauinya maka peneliti melakukan uji kreadibilitas data yang terdiri dari :

1. Meningkatkan ketekunan

2. Triangulasi

3. Mengunakan bahan referensi

\section{Teknik Analisis Data}

Metode analisa data pada penelitian ini mengunakan pendekatan kualitatif deskriptif pada pendekatan kualitatif atau analisa non statistic yang bersifat melukiskan atau menggambarkan suatu fenomena sebagaimana adanya. Data yang sudah diperoleh dianalisa dan dievaluasi dengan membandingkan dengan teori yang ada untuk menemukan kemungkinan adanya permasalahan guna kelancaran proses produksi bahan baku atas sistem yang dimiliki oleh perusahaan.

\section{ANALISIS DAN PEMBAHASAN}

Analisis Kebijakan Penerapan Perusahaan Terkait Standart Akuntansi persediaan bahan baku :

1. Kebijakan pencatatan persediaan bahan baku

Pencatatan persediaan bahan baku UD. XYZ di Sidoarjo melaksanakan sistem pencatatan prepentual, menurut Mulyadi (2014:100) teknik pencatatan perpentual yaitu pencatatan mengenai jumlah persediaan yang dilakukan secara terus-terusan dan persediaan dapat diketahui setiap waktu. Pencatatan pada pesediaan bahan baku diselengarakan oleh bagian akuntansi dan bagian gudang. Menurut bagian gudang UD. XYZ di Sidoarjo, bahan baku yang terdapat dalam gudang dibuatkan kartu stock, sehingga melalui kartu stock ini sewaktu - waktu bisa didapati secara langsung kapasitas persediaan yang terdapat di dalam gudang penyimpanan tanpa harus melakukan inventarisasi fisik dahulu. Dengan begitu, meskipun perusahaan telah mengadakan daftar pembaruan persediaan yang panjang, tetapi stock opname dilaksanakan pada setiap akhir minggu oleh petugas gudang dan melakukan stock opname kembali setiap bulan oleh bagian akuntansi, menurut bagian akuntansi pada UD. XYZ di Sidoarjo setiap akhir bulan bahan baku di stock opname.

2. Kebijakan Penilaian Bahan Baku

Evaluasi bahan baku UD. XYZ di Sidoarjo berdasarkan bagian akuntansi dalam melakukan penghitungan FIFO. Penggunaan teknik FIFO bisa dilihat dari penerapan bahan baku yang terpakai yaitu bahan baku dengan kualitas yang lebih awal atau bahan baku yang kualitas belum mengklaim pengembangan dari supplier (masuk pertama dan keluar pertama), berdasarkan bagian akuntansi pengunaan 
E-ISSN 2621-6442

teknik ini digunakan karena barang yang masuk gudang awal akan dikeluarkan lebih dahulu, hal ini dapat mengurangi rasio adanya barang yang cacat dikarenakan terlalu lama di penimbunan.

Perusahaan melakukan teknik ini dikarenakan jika memakai teknik LIFO barang yang telah sampai di awal akan terlalu lama digudang dan dapat menambah biaya penyimpanan, selain itu barang juga akan mengalami penyusutan bobot.

Tatanan Penanganan Internal berdasarkan Persediaan Pengkaji melaksanakan terhadap penilaian terhadap 5 bagian pada tatanan penanganan yakni ruang lingkup penanganan, aksi penanganan, perhitungan rasio, fakta serta korespondesi serta juga pengamanan kapasitas, agar mendapatkan pemberitahuan serta hasil perhitungan pengkaji memacu pada tatanan dan cara penanganan persediaan adapun selanjutnya

1. Tatanan serta cara penerapan Persediaan Berikut ini adalah penjelasan dari sistem dan prosedur pada UD. XYZ di Sidoarjo.

1) Prosedur Permintaan dan Pengeluaran Bahan Baku dari Gudang

2) Prosedur Pengembalian Bahan Baku ke Gudang

2. Komponen Sistem Penngendalian Internal Persediaan

1) Lingkungan pengelolaan, internal atas stok persediaan pada perusahaan dijelaskan berdasarkan faktor yang menyusun lingkungan pengendalian.

2) Aktivitas Pengelolaan UD. XYZ di Sidoarjo menyangkut adanya kebijakan prosedur yang dijalankan di perusahaan yang dapat menjamin sistem yang telah berjalan dengan ekfektif. Aktifitas pengelolaan yang dilakukan perusahaan.

3) Penaksiran Resiko Bahan baku yang dipakai melakukan proses produksi di UD. XYZ di Sidoarjo yaitu plastik bekas. Apabila terjadi penumpukan bahan baku, bahan tersebut akan rentan sekali dengan kecacatan maupun kerusakan diantaranya dimakan rayap, hal terseburt dapat menyebabkan kerugian pada perusahaan, sehingga dapat mengantisipasinya dengan melakukan penyetokan mingguan dan penyetokan bulanan.

Persediaan opname untuk mingguan dilaksanakan supaya pengamatan serta bahan baku lebih efesien serta dapat mempermudah ketika akan melaksanakan persediaan opname bulanan. Persediaan opname mingguan dilakukan oleh bagian gudang dan persediaan opname bulanan dilaksanakan oleh bagian akuntansi, selain untuk menjaga keamanan dari rasio pengambilan barang UD. XYZ di Sidoarjo menempatkan CCTV pada perusahaan. Penempatan CCTV berfungsi agar mengintai tenaga pekerja, keamanan perusahaan dan pengelolaan terhadap pemungutan barang baik dari internal maupun eksternal.

4) dan Korespondensi Tatanan dan korespondensi dalam pelaksanaan pengeluaran bahan baku dari tempat penimbunan dan pemulangan bahan baku ke tempat penimbunan. Diperoleh sebagian manfaat yang bersangkutan, cara yang dapat dilakukan arsip serta notulen yang dibutuhkan serta paparan yang diperoleh. Berikut ini akan dijelaskan Tatanan informasi dan komunikasi yang terkait dengan Tatanan permintaan dan pengembalian bahan baku:

1. Tatanan penjelasan dan Korespondensi permintaan dan Pengeluaran Bahan Baku dari tempat penyimpanan.

2. Tatanan penjelasan dan Korespondensi pemulangan Bahan Baku ke tempat penyimpanan.

5) Pemantauan tenaga Pemantauan tenaga yang laksanakan oleh UD. XYZ di Sidoarjo pengelola Perusahaan dibantu oleh bagian pemeriksaan supaya memantau keseluruhan tindakan operasional perusahaan supaya semua bagian pada perusahaan dapat melaksanakan perannya sesuai dengan Kegunaan masing-masing supaya menciptakan pengendalian internal yang efektif.

Berdasarkan pengkajian yang telah dijabarkan, dapat di simpulkan hasil pengujian yaitu sebagai berikut

Penilaian Lingkungan pada Implementasi Pengelolaan daya tampung Bahan Baku di UD. XYZ di Sidoarjo.

1. Filosofi Tata Usaha dan tenaga Kerja 
Filosofi manajemen yang diterapkan pada UD. XYZ di Sidoarjo cukup menunjang dalam. Seluruh karyawan diarahakan bisa memiliki sikap dan tindakan baik kepada semua pelanggan, mitra pemasok, termasuk pihak-pihak lain yang terkait dengan perusahaan. Untuk membuat karyawan sadar dan mengerti akan pentingnya menaati aturan, Direktur memberikan sosialisasi dan pemahaman akan pentingnya menaati aturan. semua karyawan dalam perusahaan adalah bagian dari keluarga, kedekatan antar suatu bagian dalam perusahaan tetap terjaga dan dapat dengan mudah mengetahui permasalahan terkait perusahaan agar pengendalian intern berjalan.

\section{Komitmen terhadap Integritas dan Nilai- Nilai Etika}

UD. XYZ di Sidoarjo sudah menjalankan integritas serta etika nilai untuk karyawan. Hal ini bisa dilihat peraturan yang berlaku di manajemen dalam bentuk aturan pelaksanakan, dan serta apel jam 08.00 pagi sebelum bekerja khusunya di kegiatan produksi. Termasuk di dalamnya ada doa dan pengarahan, peringatan untuk karyawan yang salah dan juga tindakan pemberhentian bila melakukan kesalahan yang fatal seperti mencuri atau berkelahi.

\section{Komitmen Terhadap Kompetensi}

Untuk recruitment karyawan, UD. XYZ di Sidoarjo, memiliki kreteria untuk staff kantor minimal D III, khusus untuk bagian operasional atau mesin serta bagian lainnya tidak terlalu melihat latar belakang pendidikan. Training, bimbingan dan pelatihan akan mempermudah karyawan beradaptasi untuk ikut kegiatan produksi. Komitmen akan kompetensi pada UD. XYZ di Sidoarjo baik sekali. Terlihat dari latar belakang pendidikan setiap karyawan dalam perusahaan tersebut.

4. Komite Audit dan Dewan

Peran komite audit adalah memantau akuntansi perusahaan serta praktik dan kebijakan pelaporan keuangan. Pada UD. XYZ di Sidoarjo belum memiliki komite audit. Internal audit mengawasi prosedur akuntansi termasuk pengendalian persediaan.

\section{Struktur Organisasi}

Struktur organisasi tersusun untuk menentukan wewenang serta tugasnya, posisi tugas, kewajiban dan hubungan antar satuan organisasi yang terdapat pada perusahaan.

\section{Penetapan Otoritas dan Tanggung Jawab}

Penetapan otoritas dan tanggung jawab merupakan pengembangan dari struktur organisasi, yang secara garis besar diwujudkan dalam bentuk pemisahan tugas serta diskripsi pekerjaan. Didalam penetapan otoritas dan tanggung jawab pada UD. XYZ di Sidoarjo belum begitu baik. Hal ini karena adanya perangkapan fungsi seperti dalam fungsi penyimpanan dan penerimaan bahan baku dirangkap oleh bagian gudang. Lalu untuk fungsi penghitungan fisik persediaan perusahaan belum mempunyai panitia penghitungan fisik. Kegiatan penghitungan masih dilakukan oleh bagian akuntansi dan gudang. Hal tersebut dapat menyebabkan tidak maksimalnya pengendalian intern yang dilaksanakan oleh perusahaan.

7. Kebijakan dan Praktik Sumber Daya Manusia

Kebijakan dan praktik sumber daya manusia manusia meliputi perekrutan karyawan baru, orientasi karyawan baru, evaluasi karyawan, kompensasi karyawan, perlindungan karyawan dan pemberhentian karyawan. Kebijakan dan praktik sumber daya manusia yang diterapkan pada UD. XYZ di Sidoarjo sudah cukup baik. Ini dapat dilihat dari kebijakan perekrutan karyawan, pemberian cuti bagi karyawan, pemberian bonus bagi karyawan serta adanya perlindungan bagi karyawan. Hal tersebut dilakukan untuk memicu mereka agar bekerja lebih baik lagi.

\section{Evaluasi Aktivitas Penerapan Pengendalian Persediaan Bahan Baku}

1. Desain Dokumen yang Baik dan Bernomor Urut Cetak

2. Pemisahan Tugas

3. Otorisasi yang Memadai atas Setiap Transaksi Bisnis

4. Mengamankan Harta dan Catatan Perusahaan Pelaksanaan.

5. Menciptakan adanya Pengecekan Independen atas Pekerjaan Karyawan Lain

\section{Evaluasi Bentuk Penaksiran Resiko pada Proses Kelancaran Produksi di UD. XYZ di Sidoarjo}

Penaksiran resiko yang dilakukan oleh UD. XYZ di Sidoarjo agar penyajian informasi persediaan bahan baku wajar dan tepat waktu sudah cukup baik. Direktur telah mengenali dan mempelajari resiko-resiko yang ada, serta membentuk aktivitas- aktivitas pengendalian yang diperlukan untuk menghadapi hal tersebut, 
E-ISSN 2621-6442

untuk penentuan resiko perusahaan mengadakan stock opname yang memeriksa kebenaran dan kewajaran jumlah dan masa pakai dari setiap bahan baku, supaya barang yang pertama masuk yang seharusnya pertama keluar, sehingga resiko kerusakan dapat diperkecil, selain itu UD. XYZ di Sidoarjo memasang CCTV disetiap sudut perusahaan sehingga dapat membantu pemantauan keseluruhan kegiatan perusahaan sehingga dapat mengantisipasi penyelewengan yang mungkin terjadi. Perusahaan sudah cukup tanggap terhadap resiko- resiko yang telah ditentukan dan perubahan-perubahan yang harus dilakukan untuk bisa bersaing di era globalisasi ini, baik dari segi peraturan dan standar baru yang harus diikuti.

\section{Evaluasi Bentuk Informasi dan Komunikasi Kinerja untuk Menunjang Kelancran Proses Produksi}

Untuk mengetahui informasi dan komunikasi persediaan bahan baku pada UD. XYZ di Sidoarjo dilakukan dengan mengambil data mengenai transaksi yang berhubungan dengan persediaan bahan baku dengan melihat dokumen serta catatan sebagai berikut:

\section{Sistem Informasi dan Komunikasi Permintaan dan Pengeluaran Bahan Baku dari Gudang}

Fungsi-fungsi yang terkait dalam permintaan dan pengeluaran bahan baku dari gudang yaitu fungsi produksi, fungsi gudang dan fungsi akuntansi. Dalam hal ini fungsi produksi bertugas meminta bahan baku yang akan diproduksi kepada bagian gudang dan juga melaporkan kepada fungsi akuntansi mengenai berapa banyak kuantitas bahan baku yang diminta. Lalu untuk fungsi gudang bertugas untuk menyiapkan seluruh bahan baku yang diminta oleh fungsi produksi setelah itu melaporkan kuantitas bahan baku yang diminta kepada fungsi akuntansi. Sedangkan fungsi akuntansi bertugas untuk mencatat pada kartu persediaan mengenai banyaknya kuantitas bahan baku yang diminta melalui laporan dari fungsi produksi dan fungsi gudang, selain itu juga membuat jurnal pemakaian bahan baku. Dalam kegiatan ini fungsi yang terkait dengan permintaan dan pengeluaran bahan baku dari gudang masih belum sesuai dengan teori yang ada. Fungsi kartu persediaan dan fungsi jurnal pada UD. XYZ di Sidoarjo dirangkap oleh satu orang yaitu oleh fungsi akuntansi, lalu untuk dokumen yang digunakan berdasarkan teori adalah bukti permintaan pengeluaran barang gudang. Bukti permintaan dan pengeluaran barang gudang disini berfungsi sebagai bukti yang digunakan untuk meminta berapa banyak kuantitas bahan baku yang dikeluarkan dari gudang dan juga sebagai bukti pengeluaran barang gudang, namun pada UD. XYZ di Sidoarjo pada kegiatan pengeluaran bahan baku dari gudang permintaan masih dilaksanakan secara lisan. Permintaan yang dilakukan secara lisan menyebabkan pada bagian gudang terkadang mengalami keterlambatan dalam memberikan bahan baku yang diminta oleh bagian produksi. Hal tersebut membuat terganggunya proses produksi. Keterlambatan tersebut karena tidak adanya bukti permintaan dan pengeluaran bahan baku, sehingga bagian gudang terkadang lupa terhadap permintaan bahan baku dari fungsi produksi. Karena pada bagian gudang dalam UD. XYZ di Sidoarjo selain bertugas sebagai penerimaan juga bertugas sebagai fungsi penyimpanan bahan baku dan barang jadi, lalu untuk catatan akuntansi pada UD. XYZ di Sidoarjo yaitu kartu gudang, kartu persediaan dan jurnal pemakaian bahan baku, dilihat dari catatan akuntansi yang digunakan berdasarkan teori yang ada, pada proses permintaan bahan baku masih ada kekurangan yaitu belum adanya kartu harga pokok produk.

2. Sistem Informasi dan Komunikasi Pengembalian Bahan Baku Dalam Guang. Funngsi yang terkait dalam pengendalian pengembalian bahan baku dalam gudang pada perusahaan yaitu : Fungsi produksi, fungsi gudang dan fungsi akuntansi, fungsi produksi bertugas sebagai mengembalikan kelebihan bahan yang tidak dipergunakan dalam produksi kemudian melaporkan ke pengembalian tersebut ke bagian akuntansi, sedangkan fungsi akuntansi bertugas untuk mencatat banyaknya bahan baku yang dikembalikan pada kartu persediaan melalui laporan dari fungsi produksi dan fungsi gudang, serta membuat jurnal umum.

Dokumen yang digunakan dalam pelaksanaan pengambilan pada UD. XYZ di Sidoarjo belum sesuai dengan teori. Karena pelaksanaan dilakukan secara lisan. Sedangkan berdasarkan teori ada beberapa dokumen digunakan sebagai dalam pengamabilan untuk sebagai bukti.

Evaluasi Bentuk Pengawasan Kinerja untuk Menunjang Kelancran Proses Proses pada UD. XYZ di Sidoarjo

Pengawasan kinerja yang ada pada UD. XYZ di Sidoarjo sudah baik. Pengawasan kinerja dilakukan oleh pemilik. Pengawasan yang dilakukan seperti memastikan apakah pengendalian internal perusahaan sudah baik atau belum, menentukan kendala informasi serta untuk memastikan apakah semua karyawan telah melakukan tanggung jawabnya secara efektif dan sudah mematuhi aturan yang telah ditetapkan agar tujuan persahaan dapat tercapai.

\section{SIMPULAN DAN SARAN}


Dapat diambil kesimpulan pengendalian intern persediaan bahan baku guna kelancaran produksi yang diterapkan pada UD. XYZ di Sidoarjo adalah:

1. Lingkungan Pengendalian

Semua faktor dalam lingkungan pengendalian pada UD. XYZ di Sidoarjo sudah cukup memadai seperti struktur organisasi sudah berjalan secara fungsional karena menunjukkan garis-garis wewenang tetapi ada perangkapan atas tanggung jawab yang kurang jelas dalam aktivitas operasional dan pengawasan yang kurang baik dalam perusahaan dikarenakan ada salah satu SOP perusahaan yang belum berjalan dengan seharusnya. Di dalam perusahaan ini belum mempunyai komite audit yang bertugas menilai pelaksanakan kegiatan serta hasil audit intern.

2. Aktivitas Pengendalian

Aktivitas pengendalian yang dilakukan dalam persediaan bahan baku masih harus ditingkatkan hal ini dikarenakan masih adanya perangkapan fungsi dalam bagian penerimaan dan penyimpanan. Namun setiap transaksi dan aktivitas perusahaan telah diotorisasi oleh bagian yang berwenang. Dokumendokumen yang digunakan untuk transaksi telah bernomor urut cetak sehingga memudahkan pengendalian terhadap persediaan. Pengawasan fisik atas persediaan dan catatatn serta pengecekan independen atas pelaksanaan juga telah memadai karena adanya kejelasan pelaksanaan tugas dan tanggung jawab.

3. Penaksiran Resiko

Penaksiran resiko yang dilakukan oleh UD. XYZ di Sidoarjo atas persediaan bahan baku sudah cukup memadai. Hal ini terlihat dari adanya tindakan antisipasi dengan adanya kamera CCTV yang dipasang pada perusahaan untuk memantau seluruh kegiatan perusahaan serta mengantisipasi penyelewengan yang mungkin terjadi. Kemudian arsip-arsip yang pentingpun sudah disimpan dengan baik dan hanya bagian yang berwenanglah yang dapat mengaksesnya. Selain itu perusahaan juga melakukan stock opname yang dilakukan setiap minggu oleh bagian gudang dan dilakukan stock opname kembali setiap bulan oleh bagian akuntansi.

4. Informasi dan Komunikasi

Pelaksanaan informasi dan komunikasi masih belum maksimal dikarenakan masih adanya perangkapan jabatan serta terdapat beberapa dokumen dan catatan akuntansi yang belum lengkap yaitu belum adanya dokumen bukti pengeluaran dan bukti pengembalian barang dari gudang.

5. Pengawasan

Kegiatan pengawasan pada UD. XYZ di Sidoarjo sudah baik, kegiatan pengawasan tersebut dilakukan oleh audit intern. Tugas audit intern tersebut yaitu secara independen melakukan pemeriksaan dan penilaian terhadap pelaksanaan prosedur dan pencatatan yang ada dalam perusahaan agar tujuan perusahaan dapat tercapai.

Saran yang diberikan Peneliti adalah karena belum adanya bukti permintaan dan pengembalian barang barang dari gudang menyebabkan masalah komunikasi antara pekerja yang terkadang membuat bahan yang diminta terlambat didatangkan, sebaiknya perusahaan membuatdokumen bukti permintaan dan pengeluaran barang gudang supaya bagian produksi dan bagian gudang mempunyai arsip tanda bukti sehingga saat terjadi selisih antara catatan barang sebagai keperluan pengolahan dan kartu persediaan bisa digunakan sebagai bukti yang kuat untuk menyelesaikan ketika adanya masalah dalam perusahaan. UD. XYZ di Sidoarjo sebaiknya lebih ditingkatkan melakukan pengawasan yang lebih terhadap kinerja operator dalam proses pengolahan bahan baku.

\section{DAFTAR PUSTAKA}

Akbar, Fachrizal Yusha. dan Muhammad Saifi. (2018). Analisis Sistem Akuntansi Persediaan Bahan Baku Dalam Upaya Mendukung Pengendalian Intern (Studi kasus pada PT. Semen Bosowa Banyuwangi). Skripsi. Malang : Universitas Brawijaya Malang.

Antika, Silvy dan Yuni Asri Ningratri, Edi Winata. (2018). Analisis Pengendalian Internal Persediaan Bahan Baku pada Pt. Arma Anugrah Abadi Medan. Skripsi. Medan : Sekolah Tinggi Ilmu Manajemen Medan.

D Darno, CW Utami, (2015). Strategic Planning Perusahaan Daerah Air Minum (PDAM) Surya Sembada Kota Surabaya With QSPM. The International Conference on Entrepreneurship ke-2 27 August 2015, Surabaya: Univ. Ciputra. 
Mitra Surabaya . Majalah Ilmiah Bijak Vol. 17, No. 1, Maret 2020, pp. 50-57, Jakarta : STIAMI

Dewi, Ita Yuliana. (2010). Analisis Pengendalian Persediaan Bahan Baku Kertas Cd Roll With Safety Stock pada Cv. Adinugraha. Skripsi. Surakarta : Universitas Sebelas Maret Surakarta.

Mufidah. (2017). Pengaruh Pengendalian Internal Persediaan Dan Sistem Informasi Akuntansi Terhadap Upaya Pencegahan Kecurangan (Fraud) Dalam Pengelolaan Persediaan pada Pt. Mitra Jambi Pratama. Skripsi. Jambi : Universitas Batanghari Jambi.

Nawawi, A. (2016). Analisis sistem pengendalian bahan baku dalam menunjang efektifitas proses produksi pada Pt. Badja Baru Palembang. Skripsi. Palembang : Universitas Muhammadiyah Palembang.

Nurlaila, Isna. (2017). Evaluasi penerapan sistem informasi akuntansi dan sistem pengendalian internal pada persediaan barang jadi di Pt. Iskandar IndahPrinting Textil surakarta. Skripsi. Surakarta : Intitut Agama Islam Negeri Surakarta.

Nurul, Chotimah, Azakiya (2017). Evaluasi Sistem Pengendalian Intern Persediaan Bahan Baku pada PT. Mutiara Pertama Bangsa. Skripsi. Surakarta : Intitut Agama Islam Negeri Surakarta.

Pengertian Sistem Pengendalian Intern. http://jasapembuatanskripsi.net/teori_sistem_pengendalian_internal

Romney, marhall, b dan Phaul Jhon Stinnbart. (2014). Kongsep pengendalian internal edisi13. Jakarta : Salemba Empat.

Romney, marhall, b dan Phaul Jhon Stinnbart. (2014). Pengertian Persediaan Bahan Baku Menurut Para Ahli Edisi13.Jakarta : Salemba Empat.

Romney, marhall, b dan Phaul Jhon Stinnbart. (2014). Sistem Informasi Akuntansi edisi13. Jakarta : Salemba Empat.

S Arya, Dwipa, Agil. (2015). evaluasi penerapan sistem pengendalian intern atas proses produksi pada Cv. Sobo Asri Banyuwangi. Skripsi. Jember : Universitas Jember.

Sambara, Thalia Ananda. (2018). Analisis penegendalian internal atas barang dagang ( studi kasus pada pt . XYZ). Skripsi. Yogyakarta : Universitas Sanata Dharma Yogyakarta.

Sidabutar, Fransisca Maya Tamars. (2018). Evaluasi Pengendalian Internal pada Sistem Pembelian Bahan Baku (Study kasus di Penerbit dan Percetakan PT. Pohon Cahaya) . Skripsi. Yogyakarta : Universitas Sanata Dharma Yogyakarta.

Silvianti, Eva. (2014). pengendalian intern persediaan bahan baku untuk kelancaran produksi pada Pt. Graphika Beton. Skripsi. Riau : Universitas Maritim Raja Ali Haji.

Tuerah, Michel Chandra. (2014) Analisis Pengendalian Persediaan Bahan Baku Ikan Tuna pada Cv. Golden Kk. Skripsi. Manado : Universitas Sam Ratulangi Manado.

Wadiyo. (2019). Pengertian Sistem Pengendalian Internal, Prinsip, Tujuan. Sidoarjo : Manajemen Keuangan Network Perum.

Wulandari, Sri. (2016). Analisis Sistem Pengendalian Internal Persediaan Bahan Baku Untuk Keberlangsungan Proses Produksi pada Perusahaan Roti Orion Kediri Tahun 2016. Skripsi. Kediri: Universitas Nusantara Pgri Kediri.

Yustadi, Heri. (2019). Analisis Penerapan Sistem Informasi Akuntansi Persediaan Bahan Baku Dalam Meningkatkan Pengendalian Intern Pada Pt. Selatan Agro Makmur Lestari Palembang. Skripsi. Palembang : Universitas Muhammadiyah Palembang. 